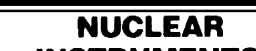

\title{
Aerosol chemical elemental mass concentration at lower free troposphere
}

\author{
Maria do Carmo Freitas ${ }^{\mathrm{a}, *}$, Isabel Dionísio ${ }^{\mathrm{a}}$, Paulo Fialho ${ }^{\mathrm{b}}$, Filipe Barata $^{\mathrm{b}}$ \\ ${ }^{a}$ Reactor-ITN, Technological and Nuclear Institute, E.N. 10, 2686-953 Sacavém, Portugal \\ ${ }^{\mathrm{b}}$ Chemistry and Physics of Atmosphere, Azores University, 9701-851 Terra Chã, Portugal
}

Available online 25 April 2007

\begin{abstract}
This paper shows the use of Instrumental neutron activation analysis (INAA) technique to determine elemental masses collected by a seven-wavelength Aethalometer instrument at the summit of Pico mountain in the Azorean archipelago, situated in the Central North Atlantic Ocean. Each sample corresponds to air particulate matter measured continuously for periods of approximately $24 \mathrm{~h}$ taken from 14th July 2001 through 14th July 2002. The statistical analysis of the coefficients of correlation between all the elements identified, permitted to establish six groups that could potentially be associated with the type of source responsible for the aerosol sampled in the lower free troposphere at the Azorean archipelago. Calculation of the synoptic back trajectories helped to corroborate the use of the iron/cesium relation as a tracer for the Saharan dust aerosol. It was demonstrated that INAA constituted an important tool to identify these events.
\end{abstract}

(C) 2007 Elsevier B.V. All rights reserved.

PACS: $29.30 . \mathrm{Kv} ; 07.88 .+\mathrm{y}$

Keywords: Chemical elements; INAA; Iron/cesium aerosol; Aethalometer; PICO-NARE

\section{Introduction}

The PICO-NARE observatory is an experimental site on the Pico Island $\left(38.47^{\circ} \mathrm{N} ; 28.40^{\circ} \mathrm{W} ; 2225 \mathrm{~m}\right.$ altitude) in the Azores archipelago, developed to provide a base for lower free troposphere measurements [1]. The installation of one Aethalometer for measuring light absorption of the aerosol, allowed the collection of approximately $24 \mathrm{~h}$ samples of aerosol in a quartz filter tape used by this instrument [2].

This site is the pathway of air masses traveling from surrounding continents (African, European, and Central and North American) that carry with them natural and anthropogenic aerosols. By analyzing the elemental composition of the aerosol samples and establishing correlations between some elements, we show a statistically valid link with the type of emission sources and/or pathways of the aerosol collected.

\footnotetext{
${ }^{*}$ Corresponding author. Tel.: + 351 219946130; fax: + 351219941039.

E-mail address: cfreitas@itn.pt (M. do Carmo Freitas).
}

Some chemical analyses can be used in order to give an insight into the provenance of the aerosols. Instrumental neutron activation technique (INAA) can be a powerful tool in this identification because this technique allows an accurate and precise determination of some mineral elements such as Fe, La, Sc and $\mathrm{Sm}[3,4]$.

\section{Experimental methods}

The elemental composition of the aerosol samples, collected by the Aethalometer, was determined by INAA.

The aerosol samples were continuously collected in quartz filters (Q250F) for periods of approximately $24 \mathrm{~h}$, from 14 July 2001 to 14 July 2002. The total number of analyzed filters (109) corresponds only to the ones that show some black and/or brown reddish coloration. The average air volume, sampled for each filter, was $5.27 \pm 0.41 \mathrm{~m}^{3}$.

The filters for analysis (blanks and samples) were cut from the strips in circular forms with an area of 
$0.950 \pm 0.086 \mathrm{~cm}^{2}$ each. The exposed side of each spot was covered with a piece of unexposed blank filter, to avoid contamination of the sample with the polyethylene top cover; the same procedure was applied to each blank in order to obtain identical geometry.

Each sample or blank sandwiched set was irradiated for $7 \mathrm{~h}$ with a neutron thermal flux of $3 \times 10^{12} \mathrm{~cm}^{-2} \mathrm{~s}^{-1}$ together with one disk ( $125 \mu \mathrm{m}$ thick and $5 \mathrm{~mm}$ diameter) of a $0.1 \% \mathrm{Au}-\mathrm{Al}$ alloy as comparator. After irradiation, samples and blanks decayed for 4-6 days and were then measured for 7 or $15 \mathrm{~h}$; after this measurement samples decayed for 4 weeks more and were again measured for 7 or $15 \mathrm{~h}$. The gamma spectra measurements for each sample were collected on a liquid hydrogen cooled hyperpure germanium detector $(1.8 \mathrm{keV}$ resolution at $1.33 \mathrm{MeV}$ and $30 \%$ relative efficiency), connected to a 4096 multi-channel analyzer. The gold alloy disk was also measured for $5 \mathrm{~min}$, with the same detector, 7 days after the end of the irradiation. The determination of the elemental composition results from the application of the $k_{0}$-standardization method $[5,6]$.

\section{Results and discussion}

The resume of the chemical elemental mass concentration and respective variability for the analyzed aerosol samples (after blank corrections) is shown in Table 1.

The information collected for each sample was organized in order to calculate the correlation coefficient matrix,

Table 1

Number of samples $(N)$, median, maximum and minimum of the mass concentration for the chemical elements identified in the 109 analyzed aerosol samples collected at the PICO-NARE observatory with one Aethalometer (model AE31)

\begin{tabular}{lrlll}
\hline $\begin{array}{l}\text { Chemical } \\
\text { element }\end{array}$ & $N$ & Median & $\begin{array}{l}\text { Maximum } \\
\left(\mathrm{ng} \mathrm{m}^{-3}\right)\end{array}$ & $\begin{array}{l}\text { Minimum } \neq 0 \\
\left(\mathrm{ng} \mathrm{m}^{-3}\right)\end{array}$ \\
\hline $\mathrm{Br}$ & 105 & 0.59 & 14.3 & 0.143 \\
$\mathrm{Na}$ & 98 & 58 & 1635 & 3.22 \\
$\mathrm{Mo}$ & 97 & 10.0 & 28.8 & 3.30 \\
$\mathrm{Sm}$ & 97 & 0.050 & 0.391 & 0.007 \\
$\mathrm{La}$ & 96 & 0.104 & 1.55 & 0.033 \\
$\mathrm{Sc}$ & 94 & 0.011 & 0.56 & 0.001 \\
$\mathrm{U}$ & 91 & 0.258 & 0.63 & 0.002 \\
$\mathrm{Hf}$ & 88 & 0.115 & 1.35 & 0.013 \\
$\mathrm{Co}$ & 86 & 0.54 & 2.05 & 0.015 \\
$\mathrm{Sb}$ & 85 & 22.6 & 257 & 0.99 \\
$\mathrm{Th}$ & 83 & 0.124 & 1.60 & 0.010 \\
$\mathrm{~K}$ & 77 & 123 & 2504 & 9.0 \\
$\mathrm{Zn}$ & 75 & 5.20 & 276 & 0.059 \\
$\mathrm{Cr}$ & 71 & 1.05 & 4.78 & 0.093 \\
$\mathrm{Fe}$ & 41 & 143 & 1745 & 65 \\
$\mathrm{Ce}$ & 32 & 0.372 & 3.00 & 0.007 \\
$\mathrm{As}$ & 22 & 1.45 & 5.05 & 0.110 \\
$\mathrm{Lu}$ & 20 & 0.018 & 0.032 & 0.010 \\
$\mathrm{~W}$ & 11 & 0.101 & 3.84 & 0.016 \\
$\mathrm{Sr}$ & 10 & 707 & 920 & 384 \\
\hline
\end{tabular}

The table was organized by ordering the information according to the number of the samples where each element was identified.
Table 2

Significant results of the correlation coefficient matrix $(r \geqslant 0.5)$ of the chemical elements associated into the five distinctive groups that were identified

\begin{tabular}{llllll}
\hline$G . I$ & $S m$ & $L a$ & $S c$ & $C r$ & $F e$ \\
\hline $\mathrm{La}$ & 0.92 & - & - & - & - \\
$\mathrm{Sc}$ & 0.90 & 0.94 & - & - & - \\
$\mathrm{Cr}$ & 0.66 & 0.62 & 0.56 & - & - \\
$\mathrm{Fe}$ & 0.87 & 0.94 & 0.96 & 0.54 & - \\
$\mathrm{Ce}$ & 0.82 & 0.88 & 0.79 & 0.61 & 0.81 \\
& & & & & \\
G. II & $H f$ & Co & Sb & & \\
$\mathrm{Co}$ & 0.48 & - & - & & \\
$\mathrm{Sb}$ & 0.80 & 0.66 & - & & \\
$\mathrm{Th}$ & 0.79 & 0.55 & 0.76 & & \\
& & & & & \\
G. III & $B r$ & $\mathrm{Zn}$ & & \\
$\mathrm{Zn}$ & 0.77 & - & & \\
$\mathrm{W}$ & 0.65 & 0.97 & & \\
& & & & \\
$G . I V$ & $B r$ & & & \\
$\mathrm{Na}$ & 0.62 & & & \\
G. $V$ & Mo & & & & \\
$\mathrm{U}$ & 0.72 & & & \\
\hline
\end{tabular}

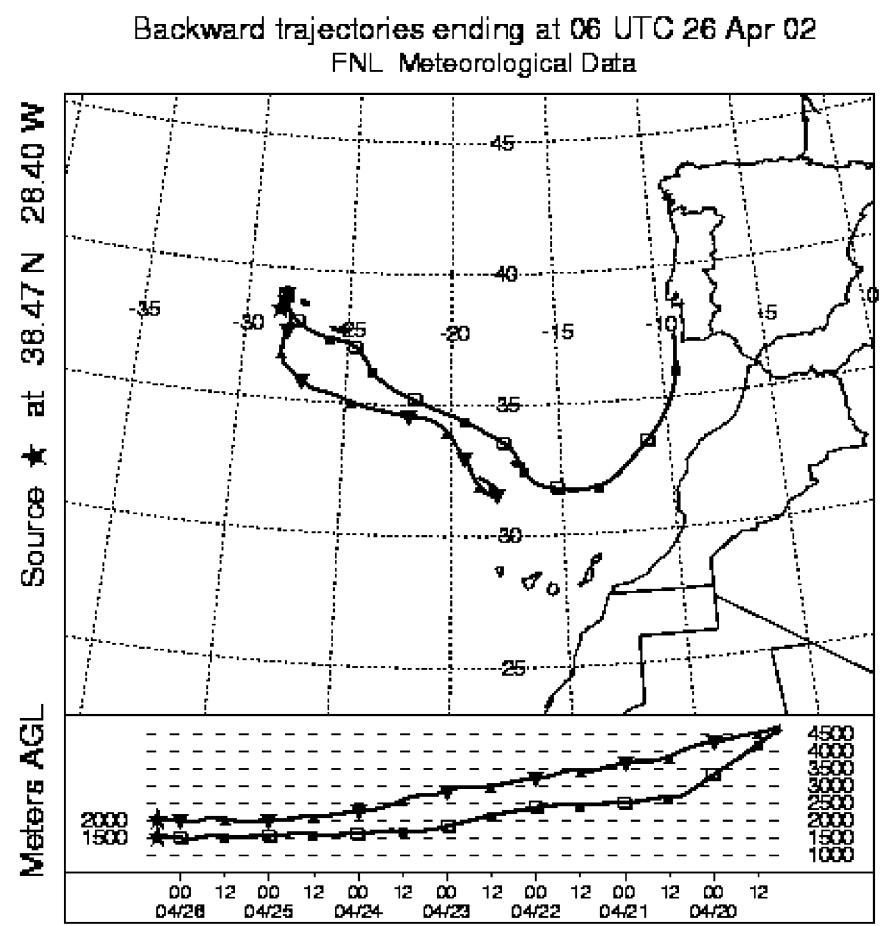

Fig. 1. Seven-day synoptic back trajectories arriving at Azorean archipelago on the 26 April 2002 at two different heights (1500 and $2000 \mathrm{~m})$. The calculations were done with the HYSPLIT model $[7,8]$.

permitting in that way to establish the relationships between the elements present in the aerosols. Five distinct associations were found $(r \geqslant 0.5)$ and are presented in Table 2. 
Analysis of the results presented in Tables 1 and 2 suggest that the G.I. classification can be split into two strongly correlating subgroups: $\mathrm{G}$.Ia with $\mathrm{Fe}$ and $\mathrm{Ce}$; G.Ib with Sm, La and Sc. The Cr element is out of both of these subgroups because although it shows some correlation $(r \approx 0.6)$, it is much weaker than the correlation between the elements of each subgroup $(r \approx 0.9)$. The presence of iron in the aerosol arriving at PICO-NARE observatory was previously associated to iron oxides resulting from the transport of Saharan dust [2,7]. The establishment of the high correlation coefficient between iron and cesium suggests that cesium could also be considered as a good tracer of the Saharan dust emissions. Taking, as an example, the 26th April 2002 (the day that corresponds to the highest cesium/iron concentration sample) and looking to the synoptic back trajectories [8-10] (Fig. 1) and the aerosol optical depth image (available at the MODIS site [11]), we support the existence of Saharan dust aerosol in the sample. The MODIS aerosol optical depth image (26 April 2002) shows a very strong dust event that went from the African continent.

\section{Conclusion}

The present paper shows that by doing the elemental characterization of the aerosol, it is possible to identify different types of associations, that we have classified as G.Ia, G.Ib, G.II through G.V. In the present paper, we only discussed the use of the G.Ib species ( $\mathrm{Fe}$ and $\mathrm{Ce}$ ) to identify the source of the aerosol as Saharan dust, and we have supported this information on the synoptic back trajectories analysis and reinforced this with the information given by the aerosol optical depth to the same region available at the MODIS site.
This simple analysis, however, is not enough to interpret and relate the other events with the respective sources, leaving that discussion for another publication.

The nuclear technique INAA confirmed its high capability to interpret these events.

\section{Acknowledgments}

Thanks are due to the Fundação para a Ciência e Tecnologia Portugal for the Project POCTI-32649-CTA2000 and grant SFRH/BD/9049/2002.

\section{References}

[1] R.E. Honrath, P. Fialho, IGAC Activities Newsletter, Issue no. 24 (2001) 20.

[2] P. Fialho, A.D.A. Hansen, R.E. Honrath, J. Aerosol Sci. 36 (2) (2005) 267.

[3] S.M. Almeida, M.A. Reis, M.C. Freitas, C.A. Pio, Nucl. Instr. and Meth. B 207 (2003) 434.

[4] S.M. Almeida, M.C. Freitas, M.A. Reis, C.A. Pio, J. Radioanal. Nucl. Chem. 257 (2003) 609.

[5] M.C. Freitas, S.M. Almeida, M.A. Reis, M.G. Ventura, J. Radioanal. Nucl. Chem. 262 (1) (2004) 235.

[6] M.C. Freitas, M.M. Farinha, M.G. Ventura, S.M. Almeida, M.A. Reis, A.M.G. Pacheco, J. Radioanal. Nucl. Chem. 263 (3) (2005) 711.

[7] P. Fialho, M.C. Freitas, F. Barata, B. Vieira, A.D.A. Hansen, R.E. Honrath, J. Aerosol Sci. 37 (2006) 1497.

[8] R.R. Draxler, G.D. Hess, NOAA Technical Memorandum ERL ARL-224, December 1997.

[9] R.R. Draxler, G.D. Hess, Aust. Meteorol. Mag. 47 (1998) 295.

[10] R. Draxler, G. Rolph, model, Web address: 〈http://www.arl.noaa. gov/ready/hysplit4.html $\rangle$, NOAA Air Resources Laboratory, Silver Spring, Maryland, 2003.

[11] P.A. Hubanks, L.A. Remer, Y.J., Kaufman, (MODIS). Images available from the MODIS-Atmosphere web site $(\langle$ http://modis-atmos. gsfc.nasa.gov $\rangle$ ). 